\title{
Association of BIM Deletion Polymorphism and BIM- $\gamma$ RNA Expression in NSCLC with EGFR Mutation
}

\author{
KAZUTOSHI ISOBE ${ }^{1}$, ATSUSHI KAKIMOTO ${ }^{1}$, TETSUO MIKAMI ${ }^{2}$, KYOHEI KABURAKI ${ }^{1}$, \\ HIROSHI KOBAYASHI ${ }^{1}$, TAKAHIRO YOSHIZAWA ${ }^{1}$, TAKASHI MAKINO ${ }^{3}$, HAJIME OTSUKA ${ }^{3}$, \\ GO SANO $^{1}$, KEISHI SUGINO ${ }^{1}$, SUSUMU SAKAMOTO ${ }^{1}$, YUJIRO TAKAI $^{1}$, \\ NAOBUMI TOCHIGI ${ }^{4}$, AKIRA IYODA ${ }^{2}$ and SAKAE HOMMA ${ }^{1}$ \\ ${ }^{1}$ Division of Respiratory Medicine, Toho University School of Medicine, Tokyo, Japan; \\ ${ }^{2}$ Division of Pathology, Toho University School of Medicine, Tokyo, Japan; \\ ${ }^{3}$ Division of Chest Surgery, Toho University School of Medicine, Tokyo, Japan; \\ ${ }^{4}$ Division of Surgical Pathology, Toho University School of Medicine, Tokyo, Japan
}

\begin{abstract}
Aim: This pilot study assessed the association of BIM deletion polymorphism and BIM RNA isoform in patients with EGFR-positive non-small cell lung cancer (NSCLC). Patients and Methods: The study included 33 patients with EGFR-positive NSCLC treated with gefitinib. BIM deletion polymorphism and BIM RNA isoform $(E L / L / S / \gamma)$ were determined by polymerase chain reaction (PCR). Results: $B I M-\gamma$ expression was significantly higher in patients with BIM deletion polymorphism than among those without BIM deletion polymorphism inside tumors $(p=0.038)$ and around tumors $(p=0.0024)$. Relative BIM- $\gamma$ expression was significantly higher in patients with BIM deletion polymorphism than among those without BIM deletion polymorphism ( $p=0.0017)$. Patients with BIM- $\gamma$ had significantly shorter progression-free survival than those without BIM- $\gamma$ (median: 304 vs. 732 days; $p=0.023$ ). Conclusion: Expression of BIM- $\gamma$ mRNA and BIM deletion
\end{abstract}

Abbreviations: BIM, BCL2-like 11; BCL, B-cell CLL/lymphoma 2; BH3, BCL2 homology domain 3; NSCLC, non-small-cell lung cancer; EGFR, epidermal growth factor receptor; EGFR-TKI, epidermal growth factor receptor tyrosine kinase inhibitor; FFPE, formalin-fixed paraffin-embedded; PFS, progression-free survival; OS, overall survival; PCR, polymerase chain reaction; RR, response rate; DCR, disease control rate; CTC, National Cancer Institute Common Terminology Criteria.

Correspondence to: Kazutoshi Isobe, Division of Respiratory Medicine, Toho University School of Medicine, 6-11-1 OmoriNishi, Ota-ku, Tokyo 143-8541, Japan. Tel: +81 337624151 ext. 6555, Fax: +81337663551, e-mail: kazutoshiisobe@med.tohou.ac.jp

Key Words: BIM, non-small cell lung cancer, epidermal growth factor receptor tyrosine kinase inhibitor. polymorphism were strongly associated. BIM- $\gamma$ overexpression may have a role in apoptosis related to EGFR-tyrosine kinase inhibitor.

Activating mutations in epidermal growth factor receptor $(E G F R)$ are promising targets in the treatment of non-small cell lung cancer (NSCLC) $(1,2)$. The frequency of $E G F R$ mutations varies by population. In North America and Western Europe, approximately $5-10 \%$ of patients with adenocarcinoma harbor mutations, whereas in East Asia approximately $60-70 \%$ of never-smokers have EGFR mutations $(3,4)$. EGFR tyrosine kinase inhibitors (EGFRTKIs) induce marked radiographic and clinical improvement in patients with EGFR mutations. EGFR-TKIs such as gefitinib, erlotinib, and afatinib are recommended for treating EGFR-mutated NSCLC $(5,6)$. NSCLC patients with such mutations who were treated with an EGFR-TKI as first-line therapy had longer progression-free survival (PFS) than those who received platinum-based chemotherapy (7-11). Therefore, detection of $E G F R$ mutations in patients with metastatic NSCLC is important for selecting individualized therapies.

Treatment resistance invariably develops within 10 to 16 months after initial EGFR-TKI treatment (12). Approximately $60 \%$ of patients with acquired resistance to EGFR-TKIs had an EGFR T790M mutation $(13,14)$. Other reported mechanisms underlying resistance are MET amplification, in $5-10 \%$ of cases $(15,16)$, and small-cell cancer transformation, in fewer than $5 \%$ of cases (17). However, approximately $30 \%$ of patients with EGFR-active mutations do not exhibit an objective response to EGFRTKI, which is known as primary resistance (18-22). Although the mechanisms of primary resistance have been investigated in several preclinical and retrospective studies, the clinical and molecular characteristics of such resistance remain poorly understood. 
BCL2-like 11 (BIM) is a pro-apoptotic member of the $\mathrm{B}$ cell CLL/lymphoma 2 (BCL2) family of proteins $(23,24)$ and is a key modulator of apoptosis triggered by EGFR-TKIs (25, 26). Faber et al. (27) used quantitative real-time polymerase chain reaction (PCR) and $B I M$ immunohistochemistry to investigate $B I M$ and $\beta$-actin RNA expression in pre-treatment tumors from 24 patients with EGFR-mutant lung cancer. The response rate to EGFR-TKIs was $44 \%$ in patients with low BIM expression and $77 \%$ in those with high BIM expression, although the difference was not significant. Recent data from the European Tarceva (EURTAC) trial showed that PFS and overall survival (OS) were shorter in patients with low/intermediate BIM mRNA levels in primary tumors than in those with high mRNA levels (PFS: 7.2 vs. 12.9 months, $p=0.0003$; OS: 22.1 vs. 28.6 months, $p=0.0364$ ) (28).

$\mathrm{Ng}$ et al. (29) reported a common intronic deletion polymorphism in the gene encoding BIM. This polymorphism switched $B I M$ splicing from exon 4 to exon 3 , which resulted in increased expression of BIM RNA isoforms lacking the proapoptotic BCL2-homology domain 3 (BH3), such as $B I M-\gamma$. The BIM isoforms with a BH3 domain were $B I M-E L, L$, and $S$. This BIM deletion polymorphism was absent in individuals from African and European populations but was present in $12 \%$ of an Asian population (29). After EGFR-TKI treatment, PFS was significantly shorter in patients with BIM deletion polymorphism than in those without this polymorphism, which suggests that reduced expression of $B I M$ with a $\mathrm{BH} 3$ domain is associated with unfavorable response to EGFRTKIs (29-33). However, few studies have examined the association between $B I M$ polymorphism and expression of $B I M$ RNA isoforms such as BIM-EL, $L, S$, and $\gamma$.

The present study investigated the association between BIM polymorphism and expression of the BIM RNA isoforms $B I M-\gamma$ and $B I M-E L / L / S$ in lung tissue from patients with $E G F R$-positive NSCLC.

\section{Patients and Methods}

Clinical samples. We studied 33 patients with EGFR mutationpositive NSCLC who were treated with EGFR-TKIs during the period from January 2008 to January 2016. BIM isoform and BIM deletion polymorphism were investigated by real-time PCR analysis of 33 formalin-fixed paraffin-embedded (FFPE) slides of surgical specimens of lung tissue.

Detection of BIM deletion polymorphism. To identify BIM deletion polymorphism, we performed 2 types of PCR analysis, using the method of $\mathrm{Ng}$ et al. (22). In brief, we used a single primer set that contained the deletion area in intron 2, as well as 2 separate primer sets designed for wild-type and deletion alleles. The DNA was subjected to PCR amplification using primers designed to detect the deletion site $(2,903 \mathrm{bp})$ in intron 2 of the BCL2L11 gene. The resulting PCR products from the deletion $(1,285 \mathrm{bp})$ and wild-type $(4,188 \mathrm{bp})$ alleles were analyzed on agarose gels. In addition, the
PCR products for the deletion (177 bp) and wild-type (174 bp) alleles were analyzed on agarose gels (30).

Detection of BIM-EL/L/S and BIM- $\gamma$. An miRNeasy FFPE Kit (Qiagen KK, Tokyo, Japan) was used to extract total RNA (including miRNA) from the FFPE sections of tumor tissue and non-tumor tissue. The extracted RNA was stored at $-80^{\circ} \mathrm{C}$ until use. cDNA was synthesized using PrimeScriptRT MasterMix (PerfectRealTime, Takara Bio Inc., Otsu, Japan). Quantitative realtime PCR was performed in a Thermal Cycler Dice Real Time System TP800 (Takara Bio Inc.), using SYBR Premix Ex Taq II (Tli RNaseH Plus, Takara Bio Inc.).

Quantification of BIM, BIM-EL/L/S, and BIM- $\gamma$. The quantitative real-time PCR primers (forward and reverse) used Perfect Real Time Primer (Takara Bio Inc.). To correct for differences in quality and quantity between samples, glyceraldehyde-3-phosphate dehydrogenase (GAPDH) was used as a reference gene. The targets were obtained from the same mRNA preparations. Relative expression of $B I M-E L / L / S$ and $B I M-\gamma$ in mRNA from tissue sections inside and around tumors, as normalized to the reference gene (GAPDH mRNA), was calculated by using the KCL22 cell line for calibration.

Clinical outcomes. We retrospectively analyzed the clinical characteristics, response rate (RR), disease control rate (DCR), and toxicity of gefitinib in patients with and without BIM- $\gamma$. We then estimated PFS and overall survival (OS) in the same groups. The PFS of patients treated with EGFR-TKI was assessed from the date gefitinib therapy started to the first sign of disease progression, as determined by computed tomographic or magnetic resonance imaging, according to the Response Evaluation Criteria in Solid Tumors (RECIST) criteria. OS was defined as the interval from the date of diagnosis until death from any cause.

Statistical analysis. Statistical analyses were conducted using the SPSS software for Windows, version 12.0 (SPSS Inc., Tokyo, Japan). Differences in relative expressions of $B I M, B I M-E L / L / S$, and $B I M-\gamma$ between patients with and without $B I M-\gamma$ were compared with the Wilcoxon rank sum test. Differences in clinical characteristics, RR, and DCR, frequency of $B I M$ deletion polymorphism, and $B I M-\gamma$ expression between patients with and without $B I M-\gamma$ were compared using the Fisher exact test. Survival curves were drawn by the Kaplan-Meier method, and statistical analysis was performed using the log-rank test. A $p$-value of less than 5\% was considered statistically significant.

This single-center study was conducted at Toho University Omori Medical Center (Tokyo, Japan) and was approved by its Human Genome/Gene Analysis Research Ethical Committee (authorization number, 24-1).

\section{Results}

BIM deletion polymorphism in EGFR-positive NSCLC. We analyzed $B I M$ deletion polymorphism in 33 patients with EGFR mutation-positive NSCLC who were treated with gefitinib. BIM deletion polymorphism was present in 4 of the 33 patients $(12.1 \%)$; heterozygous deletion was noted in all 4 patients (Table I). 
Table I. Patient characteristics $(N=33)$.

\begin{tabular}{lc}
\hline Age (years) range & $25-82$ \\
Mean & 64.7 \\
Gender & 26 \\
Male & 7 \\
Female & \\
ECOG Performance status & 21 \\
0 & 10 \\
1 & 2 \\
2 & \\
Histological pattern & 33 \\
Ad & \\
Clinical stage & 33 \\
Rec & \\
EGFR mutation at primary site & 16 \\
19del & 15 \\
L858R & 2 \\
G719C & \\
BIM deletion polymorphism & 4 \\
Yes & 29 \\
No & \\
Line of gefitinib therapy & 16 \\
First & 16 \\
Second & 1 \\
Third &
\end{tabular}

ECOG: Eastern Cooperative Oncology Group; Rec: recurrence after surgical resection; Ad: adenocarcinoma; EGFR: epidermal growth factor receptor; L858R: exon 21 L858R; 19del: exon 19 deletion; G719C: exon 18 G719C.

Clinical characteristics of patients with and without BIM deletion polymorphism. There was no significant difference in RR, DCR, or incidences of adverse events between patients with $(\mathrm{n}=8)$ and without $(\mathrm{n}=25) B I M-\gamma$ (Table II).

Association of BIM-EL/L/S and BIM- $\gamma$ expression. Expression of BIM-EL/L/S mRNA was detected inside the tumor in 12 patients, around the tumor in 3 patients, and at both sites in 9 patients; 9 patients had no such expression. Expression of $B I M-\gamma$ mRNA was detected inside the tumor in 5 patients and around the tumor in 3 patients; 25 patients had no such expression. There was no association between $B I M-E L / L / S$ and $B I M-\gamma$ expression (Table III). Relative expression was significantly higher for $B I M-\gamma$ than for $B I M-$ $E L / L / S(276 \pm 163.6 v s .12 \pm 15.1, p=0.0018)$ (Figure 1).

Association of BIM deletion polymorphism and BIM-EL/L/S expression. We compared $B I M-E L / L / S$ expression in relation to the frequency of $B I M$ polymorphism inside and/or around tumors. There was no significant difference in $B I M-E L / L / S$ expression in any comparison (Table IV).

Association of BIM deletion polymorphism and BIM- $\gamma$ expression. We compared the frequency of BIM deletion polymorphism and $B I M-\gamma$ expression inside and/or around
Table II. Clinical response and adverse events after EGFR-TKI therapy $(N=33)$.

\begin{tabular}{lccc}
\hline & $\begin{array}{c}\text { Patients with } \\
B I M-\gamma \\
(\mathrm{N}=8)\end{array}$ & $\begin{array}{c}\text { Patients without } \\
\text { BIM- } \gamma\end{array}$ & $p$-Value \\
& & & \\
& & & \\
\hline Clinical response (\%) & 62.5 & 52 & 0.60 \\
$\quad$ RR & 100 & 92 & 0.41 \\
DCR & & & \\
All adverse events (\%) & 50.0 & 32.0 & 0.35 \\
Rash & 37.5 & 24.0 & 0.45 \\
Diarrhea & 0 & 8.0 & 0.30 \\
AST/ALT & 37.5 & 16.0 & 0.20 \\
Appetite loss & 0 & 12.0 & 0.30 \\
Pneumonitis & & & \\
CTC Grade 3-5 (\%) & 12.5 & 8.0 & 0.69 \\
Rash & 0 & 8.0 & 0.41 \\
Diarrhea & 0 & 4.0 & 0.56 \\
AST/ALT & 0 & 0 & - \\
Appetite loss & 0 & 8.0 & 0.30 \\
Pneumonitis & &
\end{tabular}

RR: Response rate, DCR: disease control rate, CTC: National Cancer Institute Common Terminology Criteria.

Table III. Association of BIM-EL/L/S and BIM- $\gamma$ mRNA expression $(N=33)$.

\begin{tabular}{lcccc}
\hline & \multicolumn{4}{c}{$B I M-E L / L / S$} \\
\cline { 2 - 5 } & Inside tumor & Around tumor & Both sites & None \\
\hline$B I M-\gamma$ & & & & \\
Inside tumor & 3 & 0 & 2 & 0 \\
Around tumor & 1 & 0 & 1 & 1 \\
Both sites & 0 & 0 & 0 & 0 \\
None & 8 & 3 & 6 & 8 \\
\hline
\end{tabular}

tumors. $B I M-\gamma$ expression was significantly more frequent in patients with $B I M$ deletion polymorphism than in those without $B I M$ polymorphism inside tumors $(p=0.038)$ and around tumors $(p=0.0024)$. Absence of $B I M-\gamma$ expression was significantly more frequent in patients without $B I M$ polymorphism than in those with $B I M$ polymorphism ( $p=0.00016$ ) (Table V). Relative $B I M-\gamma$ expression was significantly higher in patients with $B I M$ deletion polymorphism than in those without BIM deletion polymorphism ( $p=0.0017$; Figure 2).

Survival and indicators of shorter PFS. We estimated PFS and OS in patients with and without $B I M-\gamma$. Patients with $B I M-\gamma$ had significantly shorter PFS than those without BIM$\gamma$ (median: $304 v s .732$ days; $p=0.023$; Figure 3 ). There was no significant difference in OS (median: 1,345 vs. 1,552 days, $p=0.24$; Figure 4 ). 
Table IV. Association of BIM deletion polymorphism and BIM-EL/L/S expression $(N=33)$.

\begin{tabular}{lccc}
\hline & \multicolumn{2}{c}{$B I M$ polymorphism } & $p$-Value \\
\cline { 2 - 3 } & Positive $(\mathrm{N}=4)$ & Negative $(\mathrm{N}=29)$ & \\
\hline$B I M-E L / L / S$ & & & \\
$\quad$ Inside tumor & 2 & 10 & 0.55 \\
Around tumor & 1 & 2 & 0.23 \\
Both sites & 0 & 9 & 0.19 \\
None & 1 & 8 & 0.91 \\
\hline
\end{tabular}

Table V. Association of BIM deletion polymorphism and BIM- $\gamma$ expression $(n=33)$.

\begin{tabular}{lccc}
\hline & \multicolumn{2}{c}{$B I M$ polymorphism } & \multirow{2}{*}{-Value } \\
\cline { 2 - 3 } & Positive (n=4) & Negative $(\mathrm{n}=29)$ & \\
\hline$B I M-\gamma$ & & & \\
Inside tumor & 2 & 3 & 0.038 \\
Around tumor & 2 & 1 & 0.0024 \\
Both sites & 0 & 0 & - \\
None & 0 & 25 & 0.00016 \\
\hline
\end{tabular}

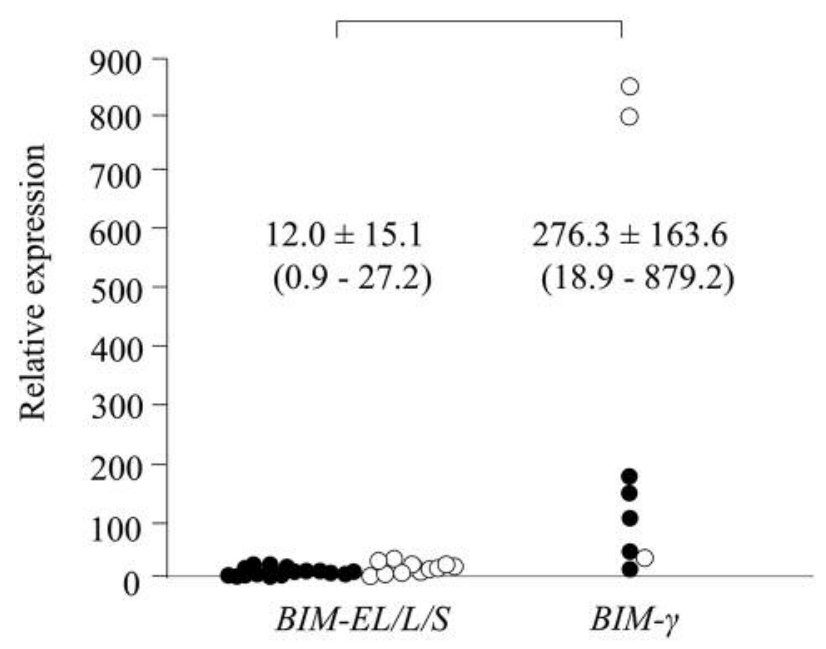

$$
p=0.0018
$$

- inside tumor

$\circ$ around tumor

Figure 1. Relative expression was significantly higher for BIM- $\gamma$ than for BIM-EL/L/S (276.3 \pm 163.6 vs. 12.0 $\pm 15.1, p=0.0018)$.

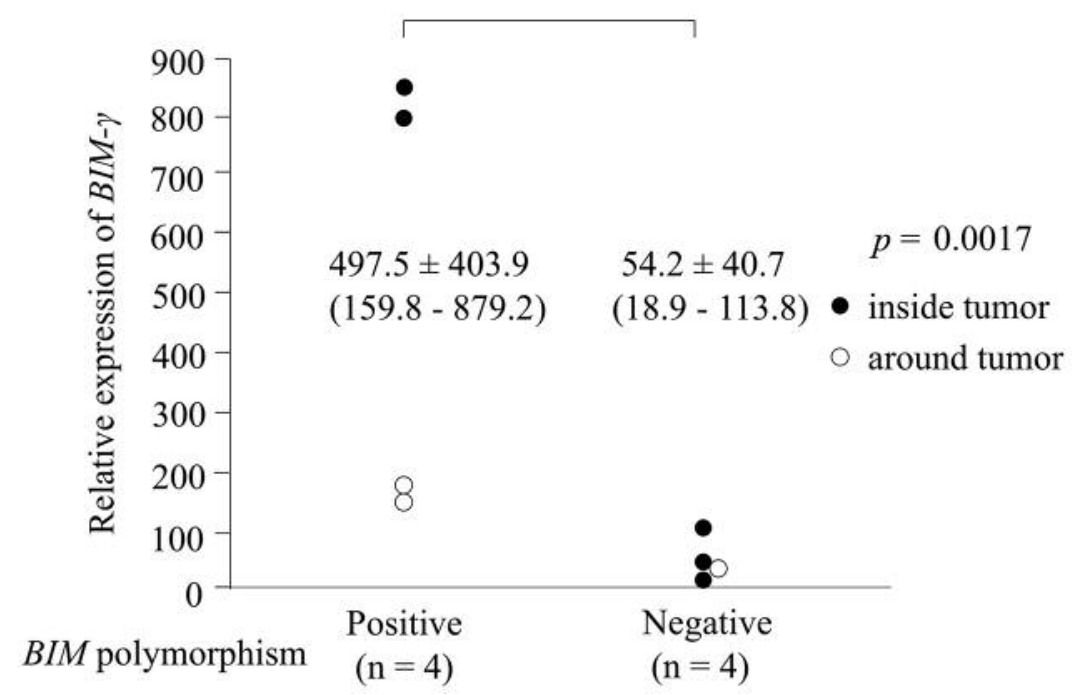

Figure 2. Frequency of BIM- $\gamma$ expression was significantly higher in patients with BIM polymorphism than in those without BIM polymorphism $(p=0.0017)$.

\section{Discussion}

The BIM deletion polymorphism is located in intron 2 of the $B I M$ gene and results in expression of BIM isoforms lacking the BH3 domain, such as BIM- $\gamma$. However, we detected both
mRNA $B I M-\gamma$ and $B I M-E L / L / S$ expression in and around tumors in patients with and without $B I M$ deletion polymorphism. We found no association between $B I M-E L / L / S$ and BIM- $\gamma$ expression, regardless of the status of BIM deletion polymorphism. Furthermore, relative expression was 


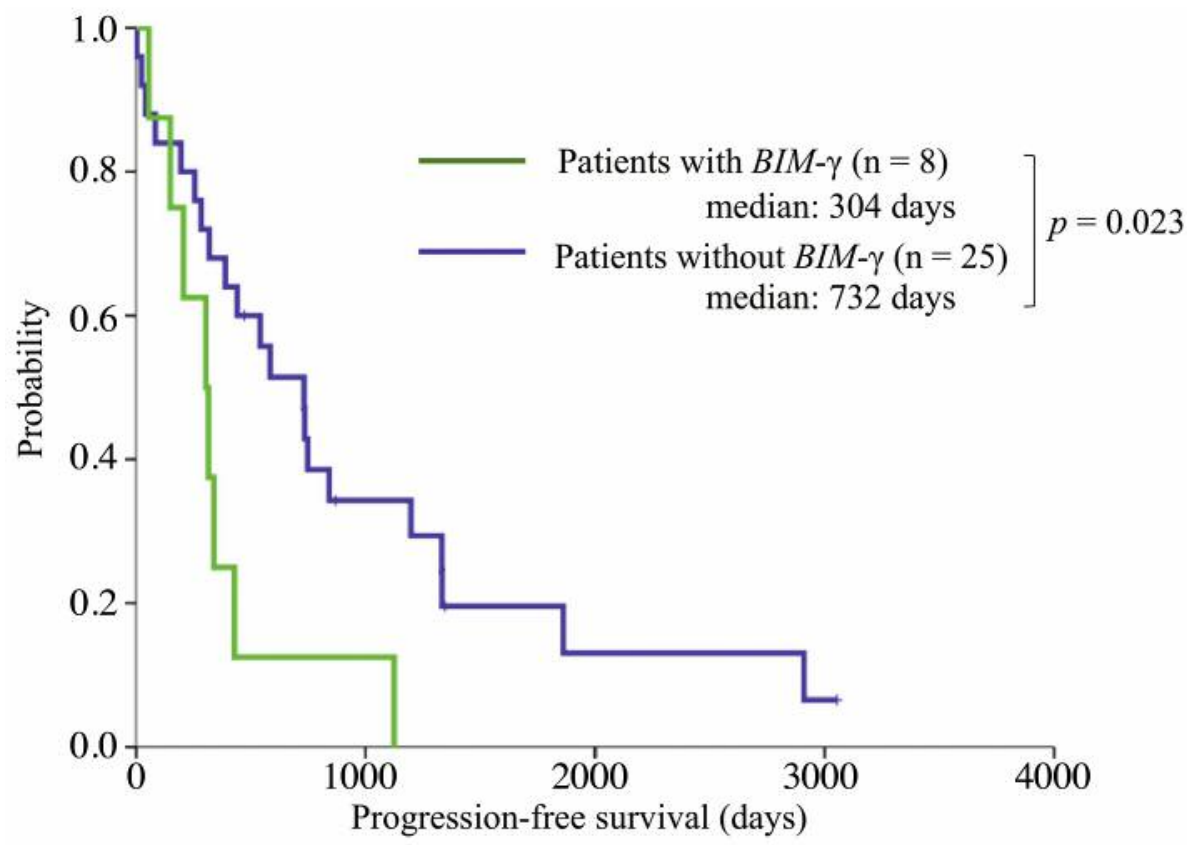

Figure 3. Kaplan-Meier curves for progression-free survival. Patients with BIM- $\gamma$ had significantly shorter progression-free survival than those without BIM- $\gamma$ (median: 304 vs. 732 days; $p=0.023$ ).

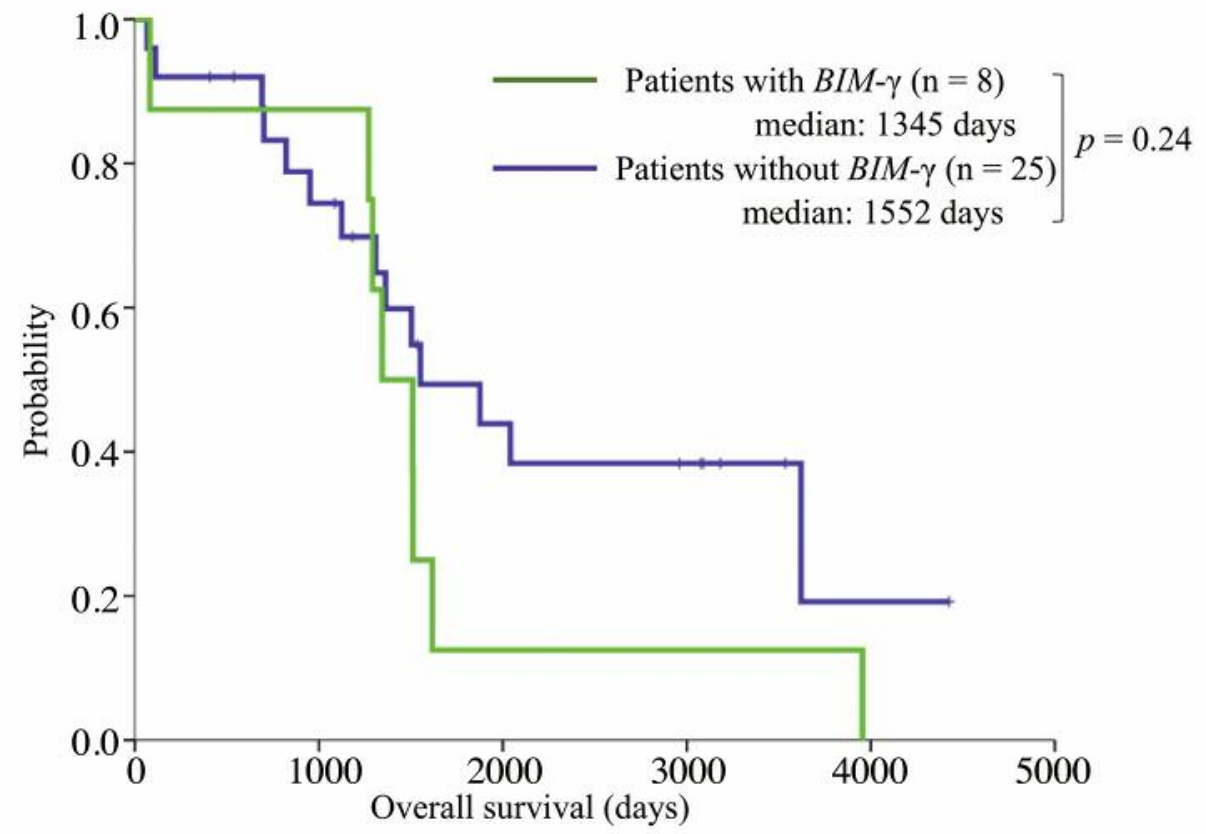

Figure 4. Kaplan-Meier curves for overall survival. Overall survival did not significantly differ between patients with and without BIM- $\gamma$ (median: 1,345 vs. 1,552 days; $p=0.24$ ).

significantly higher for $B I M-\gamma$ than for $B I M-E L / L / S$ (276 \pm 163.6 vs. $12 \pm 15.1, p=0.0018)$. Faber et al. (24) reported that BIM levels were important in determining response to targeted therapies in patients with solid tumors. This finding is consistent with research showing that cancer cells are sensitive to small changes in BIM protein concentration. 
$B I M-\gamma$, a BIM isoform that lacks the $\mathrm{BH} 3$ domain, is upregulated in most prostate cancer cell lines (34). BIM- $\gamma$ inhibits clonal growth in prostate cancer and promotes apoptosis. Interestingly, $B I M-\gamma$ was found in $13.7 \%$ (4 out of 29) of the present specimens without BIM deletion polymorphism. Relative $B I M-\gamma$ expression in patients without $B I M$ polymorphism was significantly lower than in those with $B I M$ deletion polymorphism $(p=0.0017)$. This suggests that, among the $B I M$ isoforms, overexpression of $B I M-\gamma$ suppresses TKI-related apoptosis. Further study of the mechanism of $B I M-\gamma$ expression is warranted.

One hypothesis is that $B I M$ deletion polymorphism itself results in relative resistance to EGFR-TKIs. Kuroda et al. (35) showed that cancer cells were sensitive to small changes in $B I M$ protein concentrations and that $B I M$ protein concentration had a dose-dependent effect on apoptosis and the degree of TKI resistance (35). We compared the frequency of BIM deletion polymorphism and $B I M-\gamma$ inside and/or around tumors. Patients with BIM deletion polymorphism had significantly higher $B I M-\gamma$ expression inside tumors $(p=0.038)$ and around tumors $(p=0.0024)$ than those without BIM deletion polymorphism. Absence of $B I M-\gamma$ expression was significantly more frequent in patients without BIM polymorphism than among those with BIM polymorphism $(p=0.00016)$. These findings suggest a strong association between an imbalance in $B I M$ isoforms and BIM deletion polymorphism.

Clinical characteristics, response to EGFR-TKIs, and incidences of adverse events due to EGFR-TKI did not significantly differ among patients with and without $B I M-\gamma$. Thus, clinical characteristics are not sufficient to identify patients with and without $B I M-\gamma$. However, our analysis of PFS and OS in patients with and without $B I M-\gamma$ showed that PFS was significantly shorter in patients with $B I M-\gamma$ than in those without $B I M-\gamma$ (median: $304 v s .732$ days; $p=0.023$ ). Future studies should attempt to clarify the association between $B I M-\gamma$ and PFS in patients receiving gefitinib.

The major limitation of this study is that it was a retrospective single-center study with a small sample size. A large-scale multicenter study is thus needed in order to statistically confirm the validity of our results. Clinical application of our results would require a prospective study of patients receiving gefitinib for $E G F R$ mutation-positive NSCLC with or without $B I M-\gamma$ overexpression. Bean et al. (36) reported that BIM act as sentinels that interconnect kinase signaling networks and the mitochondria-dependent apoptotic program. Karachaliou et al. (37) reported that BIM and $m T O R$ mRNA expression levels predict the outcome of erlotinib therapy in EGFR-mutant NSCLC. Future studies should examine the associations of $B I M-\gamma$ with PUMA, $m T O R$, and other apoptosis markers.

In conclusion, the present study is the first to show that $B I M-\gamma$ expression was strongly associated with $B I M$ deletion polymorphism and that $B I M-\gamma$ overexpression was associated with TKI-related apoptosis. These findings may be useful in developing treatment strategies for patients receiving EGFRTKIs for EGFR mutation-positive NSCLC.

\section{Conflicts of Interest}

The Authors declare no conflicts of interest.

\section{Acknowledgements}

The Authors thank Yoshihisa Otsuka of SRL Inc. (Tokyo, Japan) and Yusuke Hashizawa and Akimitsu Iwama of Astra Zeneca Inc. (Tokyo Japan). They are also grateful to David Kipler for his review of the language of this article. This study was supported by JSPS KAKENHI Grant Numbers JP15K09195, JP2642140, and a Research Promotion Grant from Toho University Graduate School of Medicine (No. 16-3, to K.I.).

\section{References}

1 Lynch TJ, Bell DW, Sordella R, Gurubhagavatula S, Okimoto RA, Brannigan BW, Harris PL, Haserlat SM, Supko JG, Haluska FG, Louis DN, Christiani DC, Settleman J and Haber DA: Activating mutations in the epidermal growth factor receptor underlying responsiveness of non-small-cell lung cancer to gefitinib. N Engl J Med 350: 2129-2139, 2004.

2 Paez JG, Jänne PA, Lee JC, Tracy S, Greulich H, Gabriel S, Herman P, Kaye FJ, Lindeman N, Boggon TJ, Naoki K, Sasaki H, Fujii Y, Eck MJ, Sellers WR, Johnson BE and Meyerson M: EGFR mutations in lung cancer: correlation with clinical response to gefitinib therapy. Science 304: 1497-1500, 2004.

3 Tan DS, Mok TS and Rebbeck TR: Cancer genomics: diversity and disparity across ethnicity and geography. J Clin Oncol 34: 91-101, 2016.

4 Tan DS, Yom SS, Tsao MS, Pass HI, Kelly K, Peled N, Yung RC, Wistuba II, Yatabe Y, Unger M, Mack PC, Wynes MW, Mitsudomi T, Weder W, Yankelevitz D, Herbst RS, Gandara DR, Carbone DP, Bunn PA Jr., Mok TS and Hirsch FR: The international association for the study of lung cancer consensus statement on optimizing management of EGFR mutation-positive non-small cell lung cancer: status in 2016. J Thorac Oncol 11: 946-963, 2016.

5 Masters GA, Temin S, Azzoli CG, Giaccone G, Baker S Jr, Brahmer JR, Ellis PM, Gajra A, Rackear N, Schiller JH, Smith TJ, Strawn JR, Trent D and Johnson DH: American society of clinical oncology clinical practice. systemic therapy for stage IV non-small-cell lung cancer: American society of clinical oncology clinical practice guideline update. J Clin Oncol 33: 3488-3515, 2015.

6 Kuan FC, Kuo LT, Chen MC, Yang CT, Shi CS, Teng D and Lee KD: Overall survival benefits of first-line EGFR tyrosine kinase inhibitors in EGFR-mutated non-small-cell lung cancers: a systematic review and meta-analysis. Br J Cancer 113: 1519$1528,2015$.

7 Mok TS, Wu YL, Thongprasert S, Yang CH, Chu DT, Saijo N, Sunpaweravong P, Han B, Margono B, Ichinose Y, Nishiwaki Y, Ohe Y, Yang JJ, Chewaskulyong B, Jiang H, Duffield EL, Watkins CL, Armour AA, and Fukuoka M: Gefitinib or carboplatin-paclitaxel in pulmonary adenocarcinoma. N Engl J Med 361: 947-957, 2009. 
8 Maemondo M, Inoue A, Kobayashi K, Sugawara S, Oizumi S Isobe $\mathrm{H}$, Gemma A, Harada M, Yoshizawa H, Kinoshita I, Fujita Y, Okinaga S, Hirano H, Yoshimori K, Harada T, Ogura T, Ando M, Miyazawa H, Tanaka T, Saijo Y, Hagiwara K, Morita S and Nukiwa T: Gefitinib or chemotherapy for nonsmall-cell lung cancer with mutated EGFR. N Engl J Med 362: 2380-2388, 2010

9 Mitsudomi T, Morita S, Yatabe Y, Negoro S, Okamoto I, Tsurutani J, Seto T, Satouchi M, Tada H, Hirashima T, Asami K, Katakami N, Takada M, Yoshioka H, Shibata K, Kudoh S, Shimizu E, Saito H, Toyooka S, Nakagawa K and Fukuoka M: Gefitinib versus cisplatin plus docetaxel in patients with nonsmall-cell lung cancer harbouring mutations of the epidermal growth factor receptor (WJTOG3405): an open label, randomised phase 3 trial. Lancet Oncol 11: 121-128, 2010.

10 Zhou C, Wu YL, Chen G, Feng J, Liu XQ, Wang C, Zhang S, Wang J, Zhou S, Ren S, Lu S, Zhang L, Hu C, Hu C, Luo Y, Chen L, Ye M, Huang J, Zhi X, Zhang Y, Xiu Q, Ma J, Zhang L and You C: Erlotinib versus chemotherapy as first-line treatment for patients with advanced EGFR mutation-positive non-smallcell lung cancer (OPTIMAL, CTONG-0802): a multicentre, open-label, randomised, phase 3 study. Lancet Oncol 12: 735742, 2011.

11 Yang JC, Wu YL, Schuler M, Sebastian M, Popat S, Yamamoto N, Zhou C, Hu CP, O'Byrne K, Feng J, Lu S, Huang Y, Geater SL, Lee KY, Tsai CM, Gorbunova V, Hirsh V, Bennouna J, Orlov S, Mok T, Boyer M, Su WC, Lee KH, Kato T, Massey D, Shahidi M, Zazulina V and Sequist LV: Afatinib versus cisplatinbased chemotherapy for EGFR mutation-positive lung adenocarcinoma (LUX-Lung 3 and LUX-Lung 6): analysis of overall survival data from two randomised, phase 3 trials. Lancet Oncol 16: 141-151, 2015.

12 Ohashi K, Maruvka YE, Michor F and Pao W: Epidermal growth factor receptor tyrosine kinase inhibitor-resistant disease. J Clin Oncol 31: 1070-1080, 2013.

13 Kobayashi S, Boggon TJ, Dayaram T, Jänne PA, Kocher O, Meyerson M, Johnson BE, Eck MJ, Tenen DG and Halmos B: EGFR mutation and resistance of non-small-cell lung cancer to gefitinib. N Engl J Med 352: 786-792, 2005.

14 Pao W, Miller VA, Politi KA, Riely GJ, Somwar R, Zakowski MF, Kris MG and Varmus $H$ : Acquired resistance of lung adeno-carcinomas to gefitinib or erlotinib is associated with a second mutation in the EGFR kinase domain. PLoS Med 2: e73, 2005.

15 Engelman JA, Zejnullahu K, Mitsudomi T, Song Y, Hyland C, Park JO, Lindeman N, Gale CM, Zhao X, Christensen J, Kosaka T, Holmes AJ, Rogers AM, Cappuzzo F, Mok T, Lee C, Johnson BE, Cantley LC and Jänne PA: MET amplification leads to gefitinib resistance in lung cancer by activating ERBB3 signaling. Science 316: 1039-1043, 2007.

16 Bean J, Brennan C, Shih JY, Riely G, Viale A, Wang L, Chitale D, Motoi N, Szoke J, Broderick S, Balak M, Chang WC, Yu CJ, Gazdar A, Pass H, Rusch V, Gerald W, Huang SF, Yang PC, Miller V, Ladanyi M, Yang CH and Pao W: MET amplification occurs with or without T790M mutations in EGFR mutant lung tumors with acquired resistance to gefitinib or erlotinib. Proc Natl Acad Sci USA 104: 20932-20937, 2007.

17 Sequist LV, Waltman BA, Dias-Santagata D, Digumarthy S, Turke AB, Fidias P, Bergethon K, Shaw AT, Gettinger S, Cosper AK, Akhavanfard S, Heist RS, Temel J, Christensen JG, Wain
JC, Lynch TJ, Vernovsky K, Mark EJ, Lanuti M, Iafrate AJ, Mino-Kenudson $M$ and Engelman JA: Genotypic and histological evolution of lung cancers acquiring resistance to EGFR inhibitors. Sci Transl Med 3: 75ra26, 2011.

18 Wheeler DL, Dunn EF and Harari PM: Understanding resistance to EGFR inhibitors-impact on future treatment strategies. Nat Rev Clin Oncol 7: 493-507, 2010.

19 Takeda M, Okamoto I, Fujita Y, Arao T, Ito H, Fukuoka M, Nishio $\mathrm{K}$ and Nakagawa K: De novo resistance to epidermal growth factor receptor-tyrosine kinase inhibitors in EGFR mutation-positive patients with non-small cell lung cancer. J Thorac Oncol 5: 399-400, 2010.

20 Cappuzzo F, Jänne PA, Skokan M, Finocchiaro G, Rossi E, Ligorio C, Zucali PA, Terracciano L, Toschi L, Roncalli M, Destro A, Incarbone M, Alloisio M, Santoro A and VarellaGarcia M: MET increased gene copy number and primary resistance to gefitinib therapy in non-small-cell lung cancer patients. Ann Oncol 20: 298-304, 2009.

21 Tanaka A, Sueoka-Aragane N, Nakamura T, Takeda Y, Mitsuoka M, Yamasaki F, Hayashi S, Sueoka E and Kimura S: Coexistence of positive MET FISH status with EGFR mutations signifies poor prognosis in lung adenocarcinoma patients. Lung Cancer 75: 89-94, 2012.

22 Sos ML, Koker M, Weir BA, Heynck S, Rabinovsky R, Zander T, Seeger JM, Weiss J, Fischer F, Frommolt P, Michel K, Peifer M, Mermel C, Girard L, Peyton M, Gazdar AF, Minna JD, Garraway LA, Kashkar H, Pao W, Meyerson M and Thomas RK: PTEN loss contributes to erlotinib resistance in EGFRmutant lung cancer by activation of Akt and EGFR. Cancer Res 69: 3256-3261, 2009.

23 Youle RJ and Strasser A: The BCL-2 protein family: opposing activities that mediate cell death. Nat Rev Mol Cell Biol 9: 4759, 2008

24 Faber AC, Ebi H, Costa C and Engelman JA: Apoptosis in targeted therapy responses: the role of BIM. Adv Pharmacol 65: 519-542, 2012.

25 Costa DB, Halmos B, Kumar A, Schumer ST, Huberman MS, Boggon TJ, Tenen DG and Kobayashi S: BIM mediates EGFR tyrosine kinase inhibitor-induced apoptosis in lung cancers with oncogenic EGFR mutations. PLoS Med 4: 1669-1779, 2007.

26 Gong Y, Somwar R, Politi K, Balak M, Chmielecki J, Jiang X and Pao W: Induction of BIM is essential for apoptosis triggered by EGFR kinase inhibitors in mutant EGFR-dependent lung adenocarcinomas. PLoS Med 4: e294, 2007.

27 Faber AC, Corcoran RB, Ebi H, Sequist LV, Waltman BA, Chung E, Incio J, Digumarthy SR, Pollack SF, Song Y, Muzikansky A, Lifshits E, Roberge S, Coffman EJ, Benes CH, Gómez HL, Baselga J, Arteaga CL, Rivera MN, Dias-Santagata D, Jain RK and Engelman JA: BIM expression in treatmentnaive cancers predicts responsiveness to kinase inhibitors. Cancer Discov 1: 352-365, 2011

28 Costa C, Molina MA, Drozdowskyj A, Giménez-Capitán A, Bertran-Alamillo J, Karachaliou N, Gervais R, Massuti B, Wei J, Moran T, Majem M, Felip E, Carcereny E, Garcia-Campelo R, Viteri S, Taron M, Ono M, Giannikopoulos P, Bivona T and Rosell R: The impact of EGFR T790M mutations and BIM mRNA expression on outcome in patients with EGFR-mutant NSCLC treated with erlotinib or chemotherapy in the randomized phase III EURTAC trial. Clin Cancer Res 20: 2001$2010,2014$. 
$29 \mathrm{Ng} \mathrm{KP}$, Hillmer AM, Chuah CT, Juan WC, Ko TK, Teo AS, Ariyaratne PN, Takahashi N, Sawada K, Fei Y, Soh S, Lee WH, Huang JW, Allen JC Jr, Woo XY, Nagarajan N, Kumar V, Thalamuthu A, Poh WT, Ang AL, Mya HT, How GF, Yang LY, Koh LP, Chowbay B, Chang CT, Nadarajan VS, Chng WJ, Than H, Lim LC, Goh YT, Zhang S, Poh D, Tan P, Seet JE, Ang MK, Chau NM, Ng QS, Tan DS, Soda M, Isobe K, Nöthen MM, Wong TY, Shahab A, Ruan X, Cacheux-Rataboul V, Sung WK, Tan EH, Yatabe Y, Mano H, Soo RA, Chin TM, Lim WT, Ruan $\mathrm{Y}$ and Ong ST: A common BIM deletion polymorphism mediates intrinsic resistance and inferior responses to tyrosine kinase inhibitors in cancer. Nat Med 18: 521-528, 2012.

30 Isobe K, Hata Y, Tochigi N, Kaburaki K, Kobayashi H, Makino T, Otsuka H, Sato F, Ishida F, Kikuchi N, Hirota N, Sato K, Sano G, Sugino K, Sakamoto S, Takai Y, Shibuya K, Iyoda A and Homma S: Clinical significance of BIM deletion polymorphism in non-small-cell lung cancer with epidermal growth factor receptor mutation. J Thorac Oncol 9: 483-487. 2014.

31 Zhao M, Zhang Y, Cai W, Li J, Zhou F, Cheng N, Ren R, Zhao C, Li X, Ren S, Zhou C and Hirsch FR: The Bim deletion polymorphism clinical profile and its relation with tyrosine kinase inhibitor resistance in Chinese patients with non-small cell lung cancer. Cancer 120: 2299-2307, 2014.

32 Lee JH, Lin YL, Hsu WH, Chen HY, Chang YC, Yu CJ, Shih JY, Lin CC, Chen KY, Ho CC, Laio WY, Yang PC and Yang JC: Bcl-2-like protein 11 deletion polymorphism predicts survival in advanced non-small-cell lung cancer. J Thorac Oncol 9: 13851392, 2014.

33 Nie W, Tao X, Wei H, Chen WS and Li B: The BIM deletion polymorphism is a prognostic biomarker of EGFR-TKIs response in NSCLC: A systematic review and meta-analysis. Oncotarget 6: 25696-25700, 2015.
34 Liu JW, Chandra D, Tang SH, Chopra D and Tang DG: Identification and characterization of Bimgamma, a novel proapoptotic BH3-only splice variant of Bim. Cancer Res 62: 2976-2981, 2002.

35 Kuroda J, Puthalakath H, Cragg MS, Kelly PN, Bouillet P, Huang DC, Kimura S, Ottmann OG, Druker BJ, Villunger A, Roberts AW and Strasser A: Bim and Bad mediate imatinibinduced killing of Bcr/Abl+ leukemic cells, and resistance due to their loss is overcome by a BH3 mimetic. Proc Natl Acad Sci USA 103: 14907-14912, 2006.

36 Bean GR, Ganesan YT, Dong Y, Takeda S, Liu H, Chan PM, Huang Y, Chodosh LA, Zambetti GP, Hsieh JJ and Cheng EH: PUMA and BIM are required for oncogene inactivation-induced apoptosis. Sci Signal 6: ra20, 2013.

37 Karachaliou N, Codony-Servat J, Teixidó C, Pilotto S, Drozdowskyj A, Codony-Servat C, Giménez-Capitán A, MolinaVila MA, Bertrán-Alamillo J, Gervais R, Massuti B, Morán T, Majem M, Felip E, Carcereny E, García-Campelo R, Viteri S, González-Cao M, Morales-Espinosa D, Verlicchi A, Crisetti E, Chaib I, Santarpia M, Luis Ramírez J, Bosch-Barrera J, Felipe Cardona A, de Marinis F, López-Vivanco G, Miguel Sánchez J, Vergnenegre A, Sánchez Hernández JJ, Sperduti I, Bria E and Rosell R: BIM and mTOR expression levels predict outcome to erlotinib in EGFR-mutant non-small-cell lung cancer. Sci Rep 5: 17499, 2015.
Received August 15, 2016

Revised September 10, 2016 Accepted September 21, 2016 